University of Nebraska - Lincoln

DigitalCommons@University of Nebraska - Lincoln

Publications, Agencies and Staff of the U.S.

Department of Commerce

U.S. Department of Commerce

2010

\title{
A note on the unprecedented strandings of 56 deep-diving whales along the UK and Irish coast
}

\author{
Sarah J. Dolman \\ Whale \& Dolphin Conservation Society (WDCS), Brookfield House, 38 St Paul Street, Chippenham, \\ Wiltshire, SN15 1LJ, UK \\ Eunice Pinn \\ Joint Nature Conservation Committee (JNCC), Dunnet House, 7 Thistle Place, Aberdeen, AB10 1UZ, \\ Scotland, UK \\ Robert J. Reid \\ Scottish Agricultural College (SAC), Veterinary Services Division, Wildlife Unit, Drummondhill \\ Jason P. Barley \\ Scottish Agricultural College (SAC), Veterinary Services Division, Wildlife Unit, Drummondhill, Stratherrick \\ Road, Inverness, IV2 4JZ, Scotland, UK \\ Rob Deaville \\ Institute of Zoology, Zoological Society of London, Regent's Park, London, NW1 4RY, UK \\ Eollow this and additional works at: https://digitalcommons.unl.edu/usdeptcommercepub \\ Part of the Environmental Sciences Commons
}

Dolman, Sarah J.; Pinn, Eunice; Reid, Robert J.; Barley, Jason P.; Deaville, Rob; Jepson, Paul D.; O'Connell, Mick; Berrow, Simon; Penrose, Rod S.; Stevick, Peter T.; Calderan, Susannah; Robinson, Kevin P.; Brownell, Robert L. Jr.; and Simmonds, Mark P., "A note on the unprecedented strandings of 56 deep-diving whales along the UK and Irish coast" (2010). Publications, Agencies and Staff of the U.S. Department of Commerce. 89.

https://digitalcommons.unl.edu/usdeptcommercepub/89

This Article is brought to you for free and open access by the U.S. Department of Commerce at DigitalCommons@University of Nebraska - Lincoln. It has been accepted for inclusion in Publications, Agencies and Staff of the U.S. Department of Commerce by an authorized administrator of DigitalCommons@University of Nebraska - Lincoln. 


\section{Authors}

Sarah J. Dolman, Eunice Pinn, Robert J. Reid, Jason P. Barley, Rob Deaville, Paul D. Jepson, Mick O'Connell, Simon Berrow, Rod S. Penrose, Peter T. Stevick, Susannah Calderan, Kevin P. Robinson, Robert L. Brownell Jr., and Mark P. Simmonds 


\title{
A note on the unprecedented strandings of 56 deep-diving whales along the UK and Irish coast
}

\author{
SARAH J. DOLMAN ${ }^{1,2}$, EUNICE PINN ${ }^{3}$, ROBERT J. REID ${ }^{4}$, JASON P. BARLEY ${ }^{4}$, ROB DEAVILLE ${ }^{5}$, \\ PAUL D. JEPSON ${ }^{5}$, MICK O'CONNELL ${ }^{6}$, SIMON BERROW ${ }^{6}$, ROD S. PENROSE 7 , PETER T. STEVICK ${ }^{8}$, \\ SUSANNAH CALDERAN $^{8}$, KEVIN P. ROBINSON $^{9}$, ROBERT L. BROWNELL, JR ${ }^{10}$ AND MARK P. SIMMONDS ${ }^{1}$ \\ ${ }^{1}$ Whale \& Dolphin Conservation Society (WDCS), Brookfield House, 38 St Paul Street, Chippenham, Wiltshire, SN15 1LJ, UK, \\ ${ }^{2}$ University of Aberdeen, School of Biological Sciences, Zoology Department, Tillydrone Avenue, Aberdeen, AB24 2TZ, Scotland, \\ UK, ${ }^{3}$ Joint Nature Conservation Committee (JNCC), Dunnet House, 7 Thistle Place, Aberdeen, AB1o 1 UZ, Scotland, UK, ${ }^{4}$ Scottish \\ Agricultural College (SAC), Veterinary Services Division, Wildlife Unit, Drummondhill, Stratherrick Road, Inverness, IV 2 4JZ, \\ Scotland, UK, ${ }^{5}$ Institute of Zoology, Zoological Society of London, Regent's Park, London, NW1 4 RY, UK, ${ }^{6}$ Irish Whale \& Dolphin \\ Group (IWDG), Merchant's Quay, Kilrush, County Clare, Ireland, UK, ${ }^{7}$ Cetacean Strandings Investigation Programme (CSIP), \\ Marine Environmental Monitoring, Penwalk, Llechryd, Cardigan, West Wales, SA43 2 PS, UK, ${ }^{8}$ Hebridean Whale \& Dolphin Trust \\ (HWDT), 28 Main Street, Tobermory, Isle of Mull, PA75 6NU, Scotland, UK, ${ }^{9}$ Cetacean Research \& Rescue Unit (CRRU), PO Box \\ 11307, Banff, AB45 3WB, Scotland, UK, ${ }^{10}$ Southwest Fisheries Science Center, NOAA Fisheries Service, Pacific Grove, \\ CA 93950, USA
}

\begin{abstract}
In the first seven months of 2008, eighteen Cuvier's beaked whales (Ziphius cavirostris), four Sowerby's beaked whales (Mesoplodon bidens), five unidentified beaked whales and twenty-nine long-finned pilot whales (Globicephala melas) were reported stranded in the UK and Ireland. Decomposition of those animals investigated puts the predicted time of death at mid-January. Concerns that an unusual mortality event had taken place prompted further investigations. Most carcasses were too decomposed for necropsy. A summary of findings is presented here. Although the initial stranding of five Cuvier's beaked whales in Scotland shared some similarities with atypical mass stranding events linked in time and space to mid-frequency naval sonars, there were two important differences with the remaining strandings during this period. First, the geographical range of the event was very wide and second, the strandings occurred over a prolonged period of several months. Both of these factors could be related to the fact that the mortalities occurred offshore and the carcasses drifted ashore. The cause(s) of this high number of strandings of mixed offshore cetacean species during this period remain undetermined.
\end{abstract}

Keywords: strandings, monitoring, conservation, noise, north-east Atlantic, Europe, Cuvier's beaked whale, Sowerby's beaked whale, long-finned pilot whale

Submitted 23 October 2009; accepted 4 December 2009

\section{INTRDDUCTIDN}

Between 21 January and 27 July 2008, there were unprecedented strandings of eighteen Cuvier's beaked whales (Ziphius cavirostris), four Sowerby's beaked whales (Mesoplodon bidens), five unidentified beaked whales and twenty-nine long-finned pilot whales (Globicephala melas) in Scotland, Ireland and Wales. Most were assumed to be dead upon stranding. In addition to those in the UK and Ireland, there was a mother and dependant calf pair of Sowerby's beaked whales stranded live at Calais, France on 19 January 2008: the mother died and the calf was lost alive back out to sea. Apart from two pilot whales that stranded

Corresponding author:

S.J. Dolman

Email: sarah.dolman@wdcs.org dead on Eigg in the Western Isles of Scotland on 12 March, all other animals stranded individually.

Concerns that an unusual mortality event had taken place were first raised following the strandings of five Cuvier's beaked whales (stranding numbers $6,7,10,11$ and 16 in Table 1) on Islay, Tiree, Harris and Lewis in western Scotland over a 9-day period. A further 51 strandings of deepdiving whales have since been recorded in Scotland, Ireland and Wales in this period (Table 1). The animals have been found in varying states of decomposition and as far apart as Cork, on the south coast of Ireland, and the Moray Firth, in north-east Scotland (Figure 1). Based on their states of decomposition, the suspected time of death of these animals was mid-January. The advanced states of decomposition meant that post-mortem was subsequently not possible for the majority of the stranded carcasses. However, samples have been collected from three live stranded Sowerby's beaked whales in Scotland (stranding numbers 2, 5 and 15 


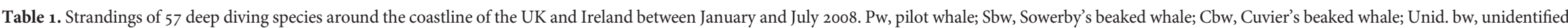
beaked whale: IWDG, stranding recorded by the Irish Whale and Dolphin Group; CSIP, stranding recorded by Cetacean Stranding Investigation Programme; SAC, Scottish Agricultural College; MEM, Marine

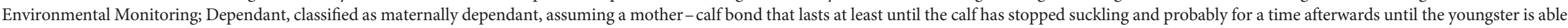
to feed independently. *samples taken but full necropsy not undertaken; **lost at sea, could have re-stranded elsewhere at later date. Natural mortalities undoubtedly overlay unusual event.

\begin{tabular}{|c|c|c|c|c|c|c|c|c|c|c|}
\hline No. & Date & Species & No. of animals & Size $(\mathbf{m})$ & Sex & Location & Condition & Necropsy & Source & Reference \\
\hline 1 & 21 January & Unid bw & 1 & $\sim 5.20$ & Unknown & Cork, Ireland & Decomposed & $\mathrm{N}$ & IWDG & 3154 \\
\hline 2 & 22 January & Sbw & 1 Dependant & 3.07 & $?$ & Moray Firth, Scotland & Live stranded & $\mathrm{Y}$ & CSIP(SAC) & Mo14/o8 \\
\hline 3 & 21 January & $\mathrm{Pw}$ & 1 & 5.32 & M & Kerry, Ireland & Decomposed & $\mathrm{N}$ & IWDG & 3136 \\
\hline 4 & 22 January & $\mathrm{Pw}$ & 1 & 2.65 & $\mathrm{~F}$ & Cork, Ireland & Live stranded & $\mathrm{N}$ & IWDG & 3139 \\
\hline 5 & 22 January & Sbw & 1 Dependant & 3.07 & M & Fortrose, Scotland & Live stranded & $\mathrm{N}$ & CSIP(SAC) & Mo14/o8 \\
\hline 6 & 3 February & $\mathrm{Cbw}$ & 1 & 6.1 & M & Islay, Scotland & Decomposed, $\sim$ mid-January & $\mathrm{N}$ & CSIP(SAC) & $\mathrm{Mo23/08}$ \\
\hline 7 & 5 February & Cbw & 1 & 5.92 & $\mathrm{~F}$ & Islay, Scotland & Decomposed, $\sim$ mid-January & $\mathrm{N}$ & CSIP(SAC) & Mo30/o8 \\
\hline 8 & 6 February & $\mathrm{Pw}$ & 1 & 4.15 & $\mathrm{~F}$ & Pembrokeshire, Wales & Live stranded & $\mathrm{Y}$ & CSIP(MEM) & SW2008/017a \\
\hline 9 & 7 February & ${ }^{* *} \mathrm{Pw}$ & 1 & $\sim 5.00$ & Unknown & Islay, Scotland & Slight decomposition (lost) & $\mathrm{N}$ & CSIP(SAC) & Mo29/08 \\
\hline 10 & 7 February & $\mathrm{Cbw}$ & 1 & 7 & $\mathrm{~F}$ & Tiree, Scotland & Decomposed, $\sim$ mid-January & $\mathrm{N}$ & CSIP(SAC) & Mo34/08 \\
\hline 11 & 7 February & Cbw & 1 & Unknown & Unknown & Harris, Scotland & Decomposed, $\sim$ mid-January & $\mathrm{N}$ & CSIP(SAC) & \\
\hline 12 & 8 February & Unid bw & 1 & $\sim 5.00$ & Unknown & Mull, Scotland & Decomposed, $\sim$ mid-January & $\mathrm{N}$ & CSIP(SAC) & Mo31/o8 \\
\hline 13 & 8 February & $\mathrm{Pw}$ & 1 neonate & 1.85 & M & Cork, Ireland & Decomposed & $\mathrm{N}$ & IWDG & 3146 \\
\hline 14 & 10 February & $\mathrm{Pw}$ & 1 & 5.8 & Unknown & Galway, Ireland & Decomposed & $\mathrm{N}$ & IWDG & 3155 \\
\hline 15 & 11 February & Sbw & 1 Dependant & 3.58 & M & Benbecula, Scotland & Fresh & $\mathrm{Y}$ & CSIP(SAC) & Mo35/o8 \\
\hline 16 & 12 February & Cbw & 1 & $\sim 6.00$ & Unknown & Lewis, Scotland & Decomposed, $\sim$ mid-January & $\mathrm{N}$ & CSIP(SAC) & Mo36/o8 \\
\hline 17 & 12 February & $\mathrm{Pw}$ & 1 & $\sim 5.00$ & Unknown & Tiree, Scotland & Dead stranded & $\mathrm{N}$ & CSIP(SAC) & Mo37/o8 \\
\hline 18 & 13 February & Unid bw & 1 & Unknown & Unknown & Pembrokeshire, Wales & Decomposed, $\sim$ mid-January & $\mathrm{N}$ & CSIP(MEM) & SW2008/028 \\
\hline 19 & 13 February & Unid bw & 1 & 5.5 & M & Sligo, Ireland & Decomposed, $\sim$ mid-January & $\mathrm{N}$ & IWDG & 3151 \\
\hline 20 & 17 February & $\mathrm{Pw}$ & 1 & $\sim 3.00$ & M & Donegal, Ireland & Decomposed & $\mathrm{N}$ & IWDG & 3156 \\
\hline 21 & 18 February & $\mathrm{Pw}$ & 1 & Unknown & Unknown & Coll, Scotland & Dead stranded & $\mathrm{N}$ & CSIP(SAC) & Mo64/o8 \\
\hline 22 & 27 February & Cbw & 1 & $\sim 7.00$ & Unknown & Galway, Ireland & Dead & $\mathrm{N}$ & IWDG & 3157 \\
\hline 23 & 2 March & Cbw & 1 & $\sim 5.50$ & Unknown & North Uist, Scotland & Decomposed, $\sim$ mid-January & $\mathrm{N}$ & CSIP(SAC) & Mo5o/o8 \\
\hline 24 & 3 March & $\mathrm{Pw}$ & 1 & Adult & Unknown & Skye, Scotland & Dead stranded & $\mathrm{N}$ & CSIP(SAC) & Mo47/08 \\
\hline 25 & 6 March & Cbw & 1 & $\sim 6.50$ & Unknown & Sligo, Ireland & Decomposed, $\sim$ mid-January & $\mathrm{N}$ & IWDG & 3161 \\
\hline 26 & $8 \mathrm{March}$ & $\mathrm{Pw}$ & 1 & $\sim 4.00$ & Unknown & Kintyre Peninsula, Scotland & Dead stranded & $\mathrm{N}$ & CSIP(SAC) & Mo51/o8 \\
\hline 27 & 9 March & $\mathrm{Pw}$ & 1 & 4.35 & M & Donegal, Ireland & Decomposed & $\mathrm{N}$ & IWDG & 3162 \\
\hline $28 / 29$ & 12 March & $\mathrm{Pw}$ & 2 & $\sim 3.50 ; \sim 4.00$ & Unknown & Eigg, Scotland & Dead stranded & $\mathrm{N}$ & CSIP(SAC) & Mo53/08-Mo54/08 \\
\hline 30 & 14 March & $\mathrm{Pw}$ & 1 & $\sim 4.00$ & Unknown & Mull, Scotland & Dead stranded & $\mathrm{N}$ & CSIP(SAC) & Mo59/o8 \\
\hline 31 & 14 March & Cbw & 1 & 5.5 & M & Mull, Scotland & Decomposed, $\sim$ mid-January & $* \mathrm{Y}$ & CSIP(SAC) & Mo55/o8 \\
\hline 32 & 15 March & $\mathrm{Pw}$ & 1 & $\sim 4.00$ & Unknown & Lewis, Scotland & Dead stranded & $\mathrm{N}$ & CSIP(SAC) & Mo58/o8 \\
\hline 33 & 16 March & $\mathrm{Pw}$ & 1 & 2.8 & $\mathrm{M}$ & Kyle of Tongue, Scotland & Dead stranded & $\mathrm{N}$ & CSIP(SAC) & Mo6o/o8 \\
\hline 34 & 19 March & $\mathrm{Pw}$ & 1 & $\sim 4.60$ & Unknown & Kerry, Ireland & Advanced decomposition & $\mathrm{N}$ & IWDG & 3166 \\
\hline 35 & 22 March & Cbw & 1 & $\sim 5.00$ & Unknown & Tiree, Scotland & Decomposed, $\sim$ mid-January & $\mathrm{N}$ & CSIP(SAC) & Mo74/o8 \\
\hline 36 & 25 March & Cbw & 1 & $\sim 8.50$ & $\mathrm{~F}$ & Moray Firth, Scotland & Decomposed, $\sim$ mid-January & $\mathrm{N}$ & CSIP(SAC) & Mo7o/08 \\
\hline 37 & 26 March & Cbw & 1 & $\sim 4.50$ & $\mathrm{M}$ & Kyle of Tongue, Scotland & Decomposed, $\sim$ mid-January & $\mathrm{N}$ & CSIP(SAC) & Mo72/08 \\
\hline 38 & 27 March & Cbw & 1 & $\sim 5.00$ & Unknown & Barra, Scotland & Advanced decomposition & $\mathrm{N}$ & CSIP(SAC) & $\mathrm{M}_{125 / 08}$ \\
\hline 39 & 28 March & $\mathrm{Pw}$ & 1 & $\sim 4.00$ & Unknown & Clare, Ireland & Advanced decomposition & $\mathrm{N}$ & IWDG & 3173 \\
\hline 40 & 30 March & $\mathrm{Cbw}$ & 1 & $\sim 6.00$ & Unknown & Lewis, Scotland & Decomposed, $\sim$ mid-January & $\mathrm{N}$ & CSIP(SAC) & Mo76/o8 \\
\hline
\end{tabular}




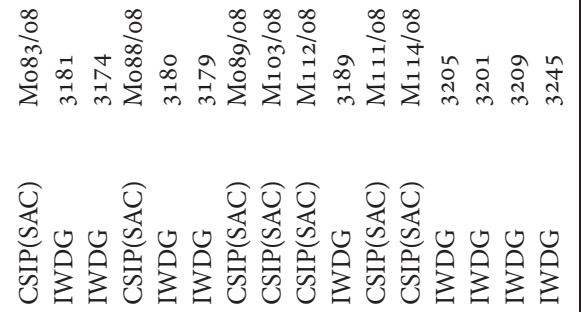

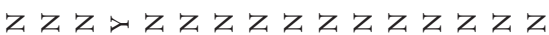
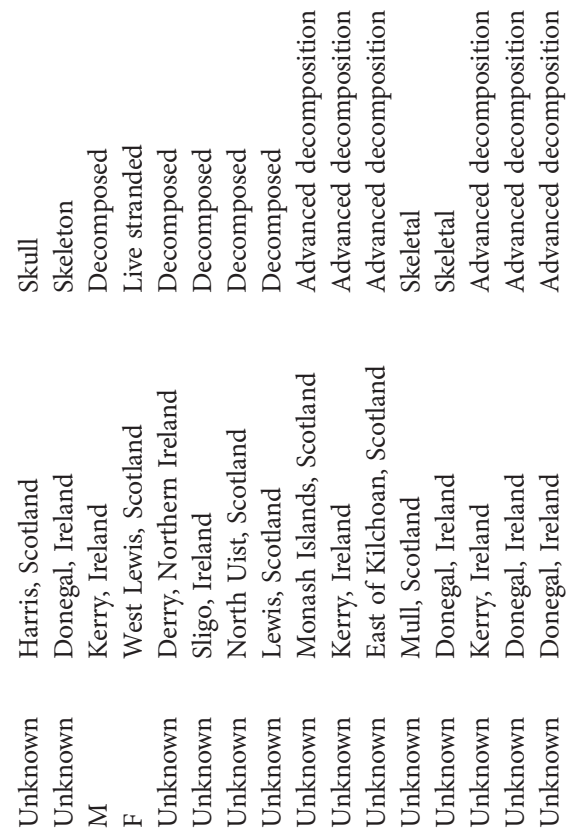

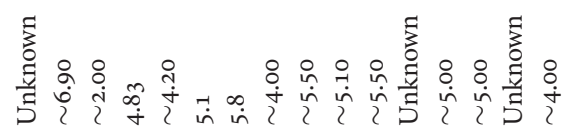
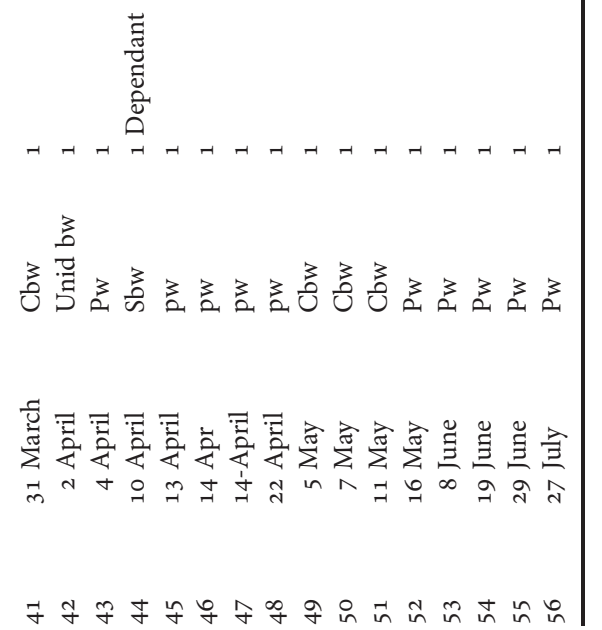

in Table 1) and the pilot whale carcass in Wales (stranding number 8 in Table 1). In two of the Sowerby's beaked whale cases (numbers 2 and 5), the cause of death was found to be maternal separation. No cause of death could be ascertained in the other Sowerby's beaked whale or for the pilot whale.

It should be noted that natural and/or unrelated mortalities undoubtedly occurred during this unusual period. As a result, some of these may have been included in Table 1, but strandings obviously not connected with this incident were excluded. For example, a pilot whale skull was found on 13 January in Clare, Ireland and was not considered to be related to this unusual mortality event.

Each of the species included in the stranding events discussed here are within their normal distribution ranges in the North Atlantic. However, the lack of population trend data for these species in the North Atlantic makes it difficult to place this mortality into a population context. The Cetacean Offshore Distribution and Abundance in the European Atlantic (CODA) survey undertaken in 2007 estimated the offshore abundance of long-finned pilot whales to be $25,100(95 \% \mathrm{CI}=13,300-47,600)$ and provided the first abundance estimate for beaked whales of 7,000 (95\% CI: 4,300-11,400) (Macleod et al., 2009). This latter figure includes Cuvier's, Sowerby's and unidentified beaked whales, as well as northern bottlenose whales.

\section{RESULTS AND DISCUSSIDN}

The number of beaked whales involved in the strandings in 2008 was unprecedented in both Ireland and the UK (Figure 2). In contrast, for pilot whales the number of strandings was unusual in Ireland but, although high, not unusual for the UK (Figure 3). For the UK, the annual average number of strandings between 1997 and 2007 for the period January to July was less than three beaked whales and six longfinned pilot whales, although strandings of this latter species ranged considerably on an annual basis from five to twentyseven (Deaville \& Jepson, 2007). During the same 11 year period in Ireland, the annual number of recorded strandings from January to July was approximately one beaked whale and less than five pilot whales (O'Connell \& Berrow, 2007; IWDG website).

Whilst the pattern of strandings reported here does not fit 'atypical' stranding events described previously, i.e. often involving more than two animals, of one or more species, stranding approximately simultaneously and alive but not in the same location (Frantzis, 1998; Brownell et al., 2004; IWC, 2005), from the number of carcasses involved and combination of species this is considered to be an atypical event.

\section{Consideration of possible causes of death}

A number of possible causes of death were investigated with inconclusive results. Unusual stranding events may be associated with anthropogenic noise sources, fisheries interactions, disease, or natural phenomenon, such as earthquakes (see review by Geraci \& Lounsbury, 2005).

\section{ANTHROPOGENIC NOISE SOURCES Military activities}

Some 'atypical' strandings of Cuvier's beaked whales in particular have been linked with mid-frequency active sonar (MFS) 

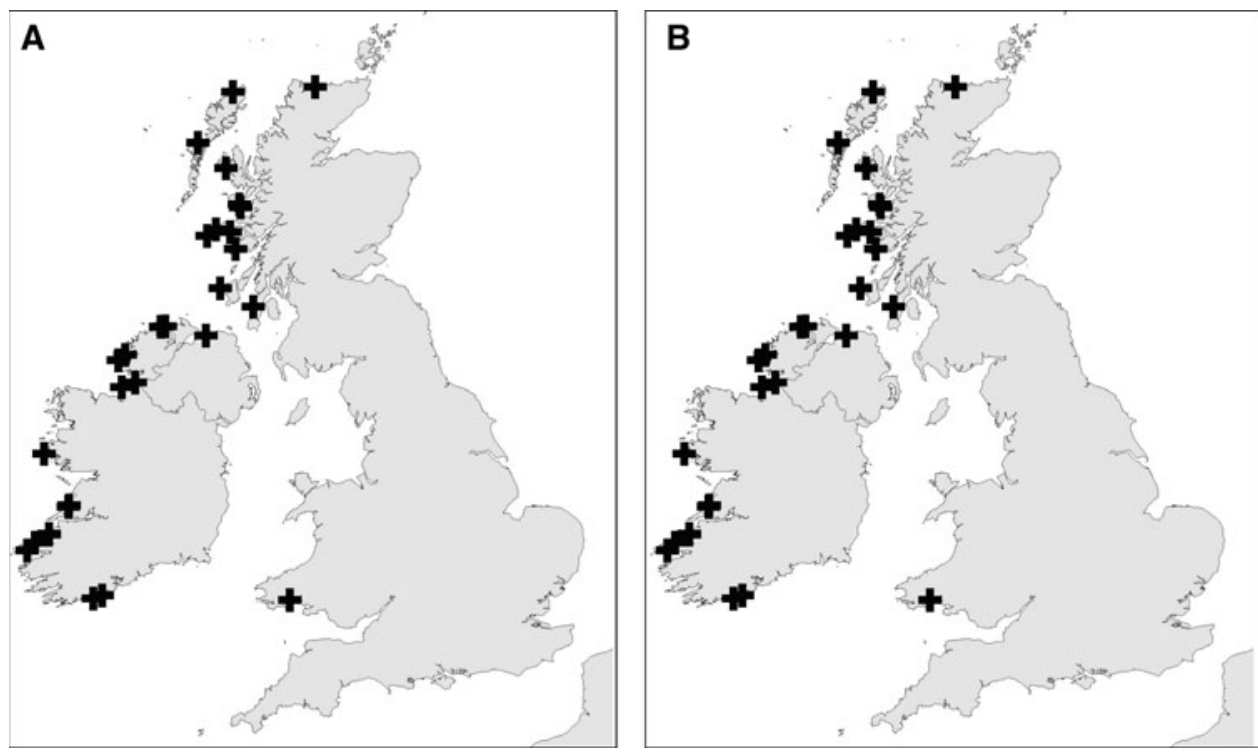

Fig. 1. Stranding distribution of (A) long-finned pilot whales and (B) beaked whales ( $\boldsymbol{\Lambda}$, Cuvier's beaked whale; $\square$, Sowerby's beaked whale; $\bigcirc$, beaked whale species) along the UK and Irish coasts between January and July 2008.

although it has not always been possible to fully investigate these events (Brownell et al., 2004; Freitas, 2004; Fernández et al., 2004; 2005a; 2005b; Martin et al., 2004; Espinosa et al., 2005; Fernández, 2006; Hohn et al., 2006). In many of these cases a definitive link could not be established, the features are described as 'the "atypical" distribution of strandings involving one or more offshore species, all stranding alive, and without evidence of common infectious or other disease processes' (Hohn et al., 2006). The mass stranding considered in this paper, however, differs in that the mortalities occurred offshore, the geographical range of the event was very wide and the strandings occurred over a prolonged period of several months.

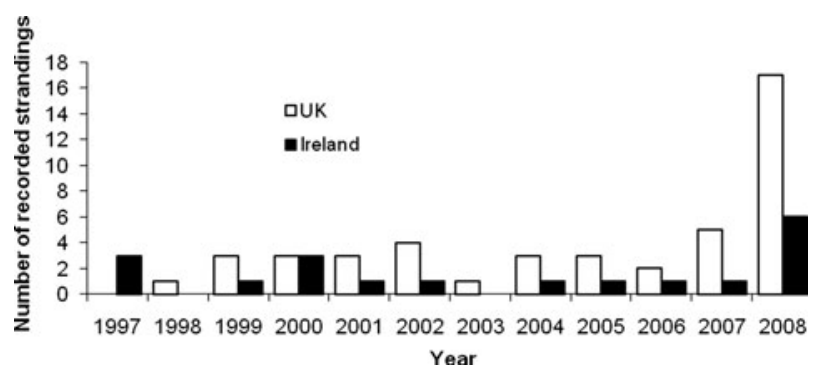

Fig. 2. Frequency distribution for number of Cuvier's and other beaked whales stranded between January and July each year in Ireland and the UK, 19972008 .

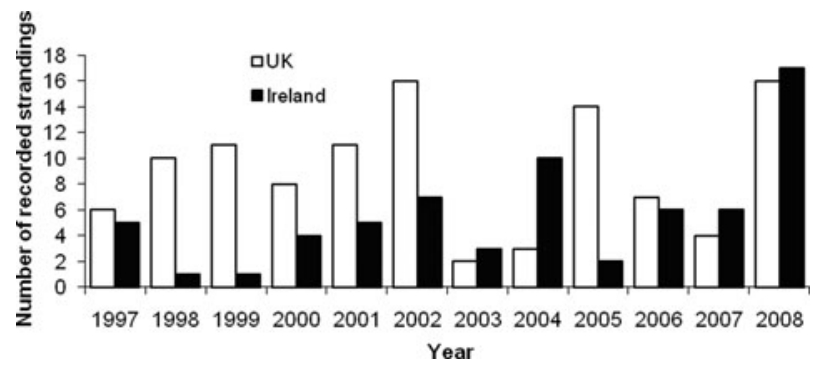

Fig. 3. Frequency distribution for number of pilot whales stranded between January and July each year in Ireland and the UK, 1997-2008.
In many of the locations where atypical mass strandings have occurred, and to which MFS use or believed to be used has been associated (e.g. Greece (Frantzis, 1998); Bahamas (Balcomb \& Claridge, 2001); Japan (Brownell et al., 2004), Canary Islands ((Espinosa et al., 2005; Fernández et al., 2005b); Madeira (Freitas, 2004); Spain (Fernández, 2006)), the shelf edge is close inshore. Therefore if MFS had a lethal or sub-lethal effect on beaked whales and other offshore cetaceans, they are more likely to live in a mass strand. In the UK and Ireland, however, the shelf edge is generally further offshore, and any animals similarly affected would be more likely to die before reaching the coastline. However, correspondence between the Whale and Dolphin Conservation Society (WDCS) and the UK Ministry of Defence (MoD), under the strict legally binding Freedom of Information legislation, has confirmed that the Royal Navy 'did not conduct any activities involving the use of sonar around these waters during the period of the strandings'. Information about the activities of other nations' naval activity is not available.

Modelling of the Atlantic Ocean currents at the calculated times of death was initiated by I. Boyd (Sea Mammal Research Unit, St Andrews University) to aid identification of possible locations of the original five Cuvier's beaked whale mortalities identified in the UK (stranding numbers 6, 7, 10, 11 and 16 in Table 1). It was intended that this information would then be used to run various scenarios to estimate where carcases from this 'source' region would be likely to strand, i.e. does the pattern fit that subsequently observed in the other strandings? Unfortunately, the initial modelling to identify a possible 'source' region proved inconclusive (I. Boyd, personal communication). Had this modelling indicated a specific area where the whales may have died, then the MoD had stated that they would revisit their records to determine if there was any military activity occurring in this location at that time (MoD email response dated 8 April 2008).

\section{Seismic surveys}

Behavioural responses have been detected in some species of cetacean in response to seismic activity including significant 
increases in fast swimming activity and directional changes, localized spatial avoidance, and subtle changes in foraging behaviour not detectable at the surface, whilst other species show no observable reaction (Stone \& Tasker, 2006; Weir, 2008; Miller et al., 2009).

Whilst seismic surveying utilizes lower frequencies than those used by beaked whales, Madsen et al. (2006) demonstrated that considerable energy at higher frequencies is also produced. However, no seismic surveys were conducted in western UK waters between December 2007 and February 2008 inclusive (UK Oil Portal). Seismic surveys occurred close to shore off north-west Ireland $\left(54^{\circ} 40^{\prime} \mathrm{N} 10^{\circ} 30^{\prime} \mathrm{W}\right)$ during 19-20, 30 December 2007 and 11-12 January 2008 (Tuffy, 2008) coinciding with the likely times of death of these animals. Although these seismic surveys coincided with the stranding event, a lack of information prevents establishing a definitive causal link.

\section{FISHERIES INTERACTIONS}

Fishing activities have been associated with the deaths of pelagic cetaceans, including beaked whales in pelagic drift-net fisheries (Read \& Wade, 2000; Moore et al., 2009). Large scale pelagic trawl fisheries exist in north-west European waters and have killed pilot whales at least (ASCOBANS, 2009). However, the deaths of the 56 long-finned pilot and beaked whales reported here are unlikely to be linked to fishing activities as the animals appear to have died at the same point in time rather than, for example, over the period of a fishing season for a particular fleet segment. There were a lack of distinctive scars and injuries on the stranded carcasses.

\section{DISEASE}

In recent decades a series of mass mortalities have been observed in marine mammal populations attributable to infection by various morbilliviruses (Kennedy, 1997; Simmonds \& Mayer, 1997; Van Bressem et al., 2001; Fernández et al., 2008).

Harmful algal blooms have been a cause of mass strandings in the US (HARRNESS, 2005). However, beaked whales would not be a candidate for this mortality source due to their deep-sea prey, more offshore habitat and the time of year that the strandings occurred.

In general, disease is a major cause of death in stranded species in the UK but there has been no recorded mass stranding event associated with disease. Where disease has been recorded as a cause of death, the species involved are generally smaller odontocetes, such as harbour porpoise (Phocoena phocoena) and common dolphin (Delphinus delphis), and are usually found as single animals (Deaville \& Jepson, 2007). Whilst there are records of mass strandings in long-finned pilot whales associated with disease (see Van Bressem et al., 2001; Fernández et al., 2008), disease in this case seems unlikely to be causal because of the mix of species that stranded; however, no analysis was available to support this.

\section{NATURAL SEISMIC EVENTS (SEAQUAKES)}

It is estimated that there are 500,000 detectable earthquakes in the world each year (USGS, 2009). In Western Europe, the majority of these occur on land but approximately $20 \%$ occur in the marine environment. Geraci \& Lounsbury (2005) suggested that the effects of seaquakes on cetaceans are likely to be similar to those of military sonar.

Between 1 December 2007 and 19 January 2008, there were 26 natural seaquakes between the Canary Islands and northern Norway and extending across to the North Atlantic Ridge (Figure 4; NEIC website). Owing to the decomposition of the animals and predicted time of death (mid-January) it is not possible to ascertain whether any of these events are linked to the mass stranding. Had a potential source location for the carcasses been identified from the modelling work undertaken by I. Boyd, it might have been possible to establish whether there was a link. However, there is a high density of beaked whales in the Bay of Biscay, yet the fact that stranding events were not reported along the Spanish/Portuguese coast might have been coincident with the earthquakes in that region.

\section{Stranding 36}

Robinson \& MacLeod (2008) reported on a Cuvier's beaked whale stranded in the Moray Firth on the east coast of Scotland (stranding 36 in Table 1). These authors proposed that the recent increase in the number of Cuvier's beaked whale strandings was indicative of a 'probable northern range expansion in our UK waters, perhaps as a result of increasing water temperature along the Atlantic frontier'. However, the range of species involved and the unprecedented nature of the 2008 event does not seem to fit with this hypothesis.

\section{Subsequent strandings}

Following the 56 strandings outlined above, an additional 17 strandings of these species have been recorded through the remainder of 2008 (Table 2). Only two of these strandings occurred in Ireland, a Sowerby's beaked whale stranded on 25 August and a Cuvier's beaked whale on 22 November (Table 2). The remainder were recorded in Scotland. On 3 September the skeletal remains of a Cuvier's beaked whale were found in a remote site on Skye. Given that these remains were skeletal they could be associated with the earlier incident (B. Reid, personal observation). After this, a further seven pilot whales, three Cuvier's beaked whales, two northern bottlenose whales, one Sowerby's and one unidentified beaked whale stranded individually in the remaining four month period from September to December 2008 (Table 2). These animals obviously died later but it is still unusual to have more than one or two Cuvier's beaked whales stranding in Scotland in a single year. The pilot whale strandings could be described as within the normal range of numbers of strandings.

\section{CDNCLUSION}

Given the advanced state of decomposition of the majority of carcasses, no information was available to ascertain the cause(s) of death. However, the states of decomposition resulted in the suspected time of death of these animals being around mid-January and it remains a possibility that a currently unidentified anthropogenic or natural factor may have been contributory to these mortalities. During the first few days after a cetacean has died it is possible to identify the time of death to within $12-24$ hours. After that it is less exact as other factors have to be considered, weather, location of carcase (below the high water mark, therefore getting cooled by water twice a day) and predator damage. 


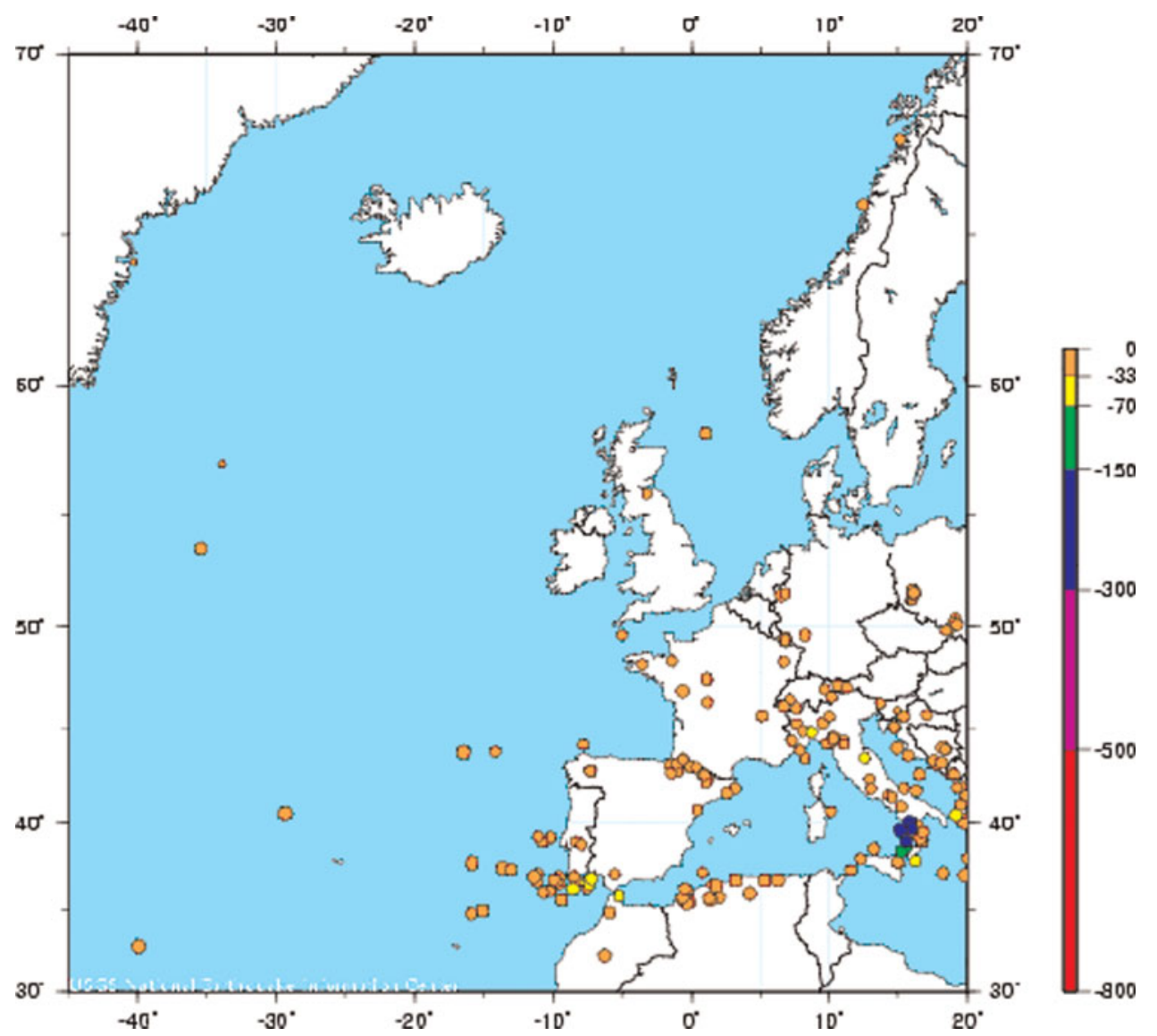

Fig. 4. Location of all earthquakes recorded from 1 December 2007 and 19 January 2008 from the Canary Islands to northern Norway (source: NEIC website). Scale represents depth $(\mathrm{km})$ of earthquake. The depth of an earthquake relates to the strength of shaking. The same magnitude earthquake at $500 \mathrm{~km}$ depth will shake the ground less than one at $20 \mathrm{~km}$ depth due to the increasing distance from the source.

It should be noted that natural and/or unrelated mortalities undoubtedly occurred during this unusual period, although these have been excluded where possible. As regards observer effort the annual number of strandings reported in Scotland since the project started stabilized after an increase in the first few years, so this is not considered an issue. In addition, larger species are more difficult to ignore even as regards to the potential environmental health issues. Furthermore, care should be taken with the interpretation of strandings data as they may not be representative for determining events that happen at sea.

Clearly, whales that die at sea can sink, refloat, drift, be eaten by predators and may never strand. A further question remains about the number of animals that died, as additional carcasses may have sunk out at sea and not stranded.

There are general lessons that can be learnt from these stranding events including the high value of dedicated strandings networks and those staff and volunteers who contribute

Table 2. Strandings of deep diving species around the coastline of the UK and Ireland for the remainder of 2008, between August and December. Pw, pilot whale; Sbw, Sowerby's beaked whale; Cbw, Cuvier's beaked whale; Nbw, northern bottlenose whale; Unid bw, unidentified beaked whale.

\begin{tabular}{|c|c|c|c|c|c|c|c|c|}
\hline No. & Date & Species & No. of animals & Size $(\mathbf{m})$ & Sex & Location & Source & Reference \\
\hline 57 & 25 August & Sbw & 1 & 4.6 & $\mathrm{~F}$ & Galway, Ireland & IWDG & 3229 \\
\hline 58 & 3 September & Cbw & 1 & Unknown & Unknown & Skye, Scotland & CSIP(SAC) & M209/o8 \\
\hline 59 & 17 September & $\mathrm{Pw}$ & 1 & $\sim 4.50$ & Unknown & North Uist, Scotland & CSIP(SAC) & $\mathrm{M} 201 / 08$ \\
\hline 60 & 2 October & $\mathrm{Pw}$ & 1 & $\sim 5.00$ & Unknown & Harris, Scotland & CSIP(SAC) & M206/o8 \\
\hline 61 & 4 October & $\mathrm{Pw}$ & 1 & 4.4 & $\mathrm{~F}$ & South Uist, Scotland & CSIP(SAC) & $\mathrm{M} 208 / 08$ \\
\hline 62 & 5 October & $\mathrm{Pw}$ & 1 & $\sim 4.00$ & Unknown & Orkney, Scotland & CSIP(SAC) & $\mathrm{M} 236 / 08$ \\
\hline 63 & 18 October & Nbw & 1 & 6.05 & $\mathrm{~F}$ & Loch Eil, Scotland & CSIP(SAC) & M212/o8 \\
\hline 64 & 23 October & Cbw & 1 & $\sim 6.00$ & Unknown & Islay, Scotland & CSIP(SAC) & $\mathrm{M} 214 / 08$ \\
\hline 65 & 28 October & $\mathrm{Pw}$ & 1 & $\sim 1.40$ & Unknown & South Uist, Scotland & CSIP(SAC) & M219/08 \\
\hline 66 & 30 October & $\mathrm{Pw}$ & 1 & $\sim 5.00$ & Unknown & Harris, Scotland & CSIP(SAC) & $\mathrm{M} 217 / 08$ \\
\hline 67 & 2 November & Ubw & 1 & $\sim 6.20$ & Unknown & South Uist, Scotland & CSIP(SAC) & $\mathrm{M} 224 / 08$ \\
\hline 68 & 10 November & Sbw & 1 & 3.94 & $\mathrm{~F}$ & Nairn, Scotland & CSIP(SAC) & $\mathrm{M} 228 / 08$ \\
\hline 69 & 19 November & Nbw & 1 & $\sim 7.00$ & M & Barassie Sands, Scotland & CSIP(SAC) & $\mathrm{M} 233 / 08$ \\
\hline 70 & 22 November & Cbw & 1 & 5.9 & Unknown & Galway, Ireland & IWDG & 3253 \\
\hline 71 & 29 November & $\mathrm{Pw}$ & 1 & 1.75 & Unknown & South Uist, Scotland & CSIP(SAC) & $\mathrm{M} 248 / 08$ \\
\hline
\end{tabular}


to them. While a properly funded and organized programme of post-mortem examination of strandings operates in the UK, a similar programme does not currently exist in the Republic of Ireland.

An online database such as that which exists in Ireland (www.iwdg.ie) should enable more efficient dissemination of information between strandings networks throughout Europe to improve the early identification of any unusual mortality events. The creation of a European strandings database is a long-standing aim of the Agreement for the Conservation of Small Cetaceans in the Baltic and North Sea (ASCOBANS). Such a database would greatly aid assessment of any future international event such as that described here. It may also help to identify any unusual historical stranding clusters across European waters.

\section{ACKNDWLEDGEMENTS}

The authors would like to thank Ian Boyd for undertaking to investigate drift modelling, also Thierry Jauniaux, Emer Rogan, IWDG and all volunteers who reported strandings to the UK and Irish stranding networks. Thanks to Paul Thompson and Caroline Weir for assistance with the figures. The first author is funded by the Whale \& Dolphin Conservation Society (WDCS). The CRRU marine strandings outfit is funded by Care for the Wild International. In addition, we would like to thank Defra, the Scottish Government and the Welsh Assembly Government who co-fund the UK Cetacean Strandings Investigation Programme. The Irish stranding database is funded by the National Parks and Wildlife Service, Northern Ireland Environment Agency, Marine Institute and the Heritage Council through ISCOPE.

\section{REFERENCES}

ASCOBANS (2009) Compilations of Annual National Reports for 2006, 2007 and 2008. Document number: MOP6/Doc.5-03. Available at http://www.service-board.de/ascobans_neu/files/MOP6_5-03_Annual NationalReports_2006-2008.pdf

Balcomb K.C. and Claridge D.E. (2001) A mass stranding of cetaceans caused by naval sonar in the Bahamas. Bahamas Journal of Science $8,1-12$.

Brownell R.L. Jr, Yamada T., Mead J.G. and van Helden A.L. (2004) Mass strandings of Cuvier's beaked whales in Japan: US naval acoustic link? Paper presented to the Scientific Committee at the 56th Meeting of the International Whaling Commission, 29 June-10 July 2004, Sorrento, Italy. SC/56/E 37 .

Deaville R. and Jepson P.D. (2007) UK Cetacean Strandings Investigative Programme Annual Report to Defra for the period 1 January-31 December 2006. Available at: http://www.defra.gov.uk/wildlifecountryside/resprog/findings/csip/csip-ar2006.pdf

Espinosa A., Arbelo M., Castro P., Martín V., Gallardo T. and Fernández A. (2005) New beaked whale mass stranding in Canary Islands associated with naval military exercises (Majestic Eagle 2004). In 19th Annual Conference of the European Cetacean Society and Associated Workshops, 2-7 April 2005, La Rochelle, France. La Rochelle: European Cetacean Society, p. 95.

Fernández A. (2006) Beaked whale (Ziphius cavirostris) mass stranding on Almería's coasts in southern Spain, 26-27 January 2006. Report of the University of Las Palmas de Gran Canaria, Canary Islands.
Fernández A., Arbelo M., Deaville R., Patterson I.A.P., Castro P., Baker J.R., Degollada E., Ross H.M., Herráez P., Pocknell A.M., Rodríguez E., Howie F.E., Espinosa A., Reid R.J., Jaber J.R., Martin V., Cunningham A.A. and Jepson P.D. (2004) Pathology: whales, sonar and decompression sickness. Nature 428, $1-2$.

Fernández A., Edwards J.F., Rodriguez F., Espinosa de los Morteros A., Herraez P., Casstro P., Jaber J.R., Martin V. and Arbelo M. (2005a) 'Gas and fat embolic syndrome' involving a mass stranding of beaked whales (Family Ziphiidae) exposed to anthropogenic sonar signals. Veterinary Pathology 42, 446-457.

Fernández A., Mendez M., Sierra E., Godhino A., Herráez P., Espinosa A., Rodríguez F. and Arbelo M. (2005b) New gas and fat embolic pathology in beaked whales stranded in the Canary Islands. In 19th Annual Conference of the European Cetacean Society and Associated Workshops, 2-7 April 2005, La Rochelle, France. La Rochelle: European Cetacean Society, p.95.

Fernández A., Esperon A.H., Espinosa de los Monteros A., Lovel C., Bernabé A., Sandez-Vizcaino A., Verborgh P., De Stephenis R., Coledano F. and Bayón A. (2008) Morbillivirus and pilot whale deaths, Mediterranean Sea. Emerging Infectious Diseases 14, 742-794.

Frantzis A. (1998) Does acoustic testing strand whales? Nature 392, 29

Freitas L. (2004) The stranding of three Cuvier's beaked whales Ziphius cavirostris in Madeira archipelago-May 2000. ECS Newsletter 42 (Special Issue), $28-32$.

Geraci J.R. and Lounsbury V.R. (2005) Marine mammals ashore: a field guide for strandings. Baltimore, MD: National Aquarium in Baltimore, $305 \mathrm{pp}$.

HARRNESS (2005) Harmful Algal Research and Response: A National Environmental Science Strategy 2005-2015. Ramsdell J.S., Anderson D.M. and Glibert P.M. (eds) Washington, DC: Ecological Society of America, $96 \mathrm{pp}$.

Hohn A.A., Rotstein D.S., Harms C.A. and Southall B.L. (2006) Report on marine mammal unusual mortality event UMESE0501Sp: multi species stranding of short-finned pilot whales (Globicephala macrorhynchus), minke whale (Balaenoptera acutorostrata) and dwarf sperm whales (Kogia sima) in North Carolina, 15-16 January 2005. NOAA Technical Memorandum NMFS-SEFSC 537. Washington, DC: National Oceanic and Atmospheric Administration. Available at: http://www.nmfs.noaa.gov/pr/pdfs/health/umese0501sp.pdf

International Whaling Commission (IWC) (2005) Report of the scientific committee. Journal of Cetacean Research and Management 7 (Supplement), 1-62.

Kennedy S. (1997) Morbillivirus infections in aquatic mammals. Journal of Comparative Pathology 119, 201-225.

Macleod K., Burt M.L., Cañadas A., Rogan E., Santos B., Uriarte A., Van Canneyt O., Vázquez J.A. and Hammond P.S. (2009) Designbased estimates of cetacean abundance in offshore European Atlantic Waters. CODA Appendix 1. Unpublished. Available at: http:// biology.st-andrews.ac.uk/coda/. Last accepted on 21 January 2010.

Madsen P.T., Johnson M., Miller P.J.O., Aguilar Soto N., Lynch J. and Tyack P. (2006) Quantitative measures of air-gun pulses recorded on sperm whales (Physeter macrocephalus) using acoustic tags during controlled exposure experiments. Journal of the Acoustical Society of America 120, 2366-2379.

Martin V., Servidio A. and Garciua S. (2004) Mass strandings of beaked whales in the Canary Islands. ECS Newsletter 42 (Special Issue), 33-36.

Miller P.J.O., Johnson M.P., Madsen P.T., Biassoni N., Quero M. and Tyack P.L. (2009) Using at-sea experiments to study the effects of airguns on the foraging behaviour of sperm whales in the Gulf of Mexico. Deep-Sea Research 56, 1168-1181. 
Moore J.E., Wallace B.P., Lewison R.L., Žydelis R., Cox T.M. and Crowder L.B. (2009) A review of marine mammal, sea turtle and seabird bycatch in USA fisheries and the role of policy in shaping management. Marine Policy, 33, 435-451.

O'Connell M. and Berrow S. (2007) Records from the Irish Whale and Dolphin Group for 2006. Irish Naturalists' Journal 28, 459-466.

Read A.J. and Wade P.R. (2000) Status of marine mammals in the United States. Conservation Biology 4, 929-940.

Robinson K.P. and MacLeod C.D. (2008) First stranding record of a Cuvier's beaked whale (Ziphius cavirostris) in the Moray Firth in north-east Scotland. JMBA Biodiversity Records No. 6266. Available at: http://www.mba.ac.uk/jmba/pdf/6266.pdf

Simmonds M.P. and Mayer S. (1997) An evaluation of environmental and other factors in some recent marine mammal mortalities in Europe: implications for conservation and management. Environmental Review 5, 89-98.

Stone C.J and Tasker M.L. (2006) The effects of seismic airguns on cetaceans in UK waters. Journal of Cetacean Research and Management 8, 247-254.

Tuffy P. (2008) MMO Report for Statoil. Irish Whale and Dolphin Group: Unpublished Report to CLIENT.
USGS (2009) On-line resource: US Geological Survey Earthquake Hazards Program. Available at: http://earthquake.usgs.gov/ (last accessed on 19 February 2009).

Van Bressem M.F., Van Waerebeek K., Jepson P.D., Raga J.A., Duignan P.J., Nielsen O., Di Beneditto A.P., Siciliano S., Ramos R., Kant W., Peddemors V., Kinoshita R., Ross P.S., Lopez-Fernández A., Evans K., Crespo E. and Barrett T. (2001). An insight into the epidemiology of dolphin morbillivirus worldwide. Veterinary Microbiology 81, 287-304.

and

Weir C.R. (2008) Short-finned pilot whales (Globicephala macrorhynchus) respond to an airgun ramp-up procedure off Gabon. Aquatic Mammals 34, 349-354.

\section{Correspondence should be addressed to:}

S.J. Dolman

University of Aberdeen

School of Biological Sciences

Zoology Department

Tillydrone Avenue, Aberdeen

AB24 2TZ, Scotland, UK

email: sarah.dolman@wdcs.org 